\title{
Dynamics of vegetation along and adjacent to an ephemeral channel
}

\author{
MICHAEL A. SMITH, JERROLD L. DODD, QUENTIN D. SKINNER, AND J. DANIEL \\ RODGERS
}

Authors are professors (first 3) and associate professor, Range Management Department, University of Wyoming, Laramie 82071 .

\section{Abstract}

Ephemeral channels may be greater contributors to nonpoint sediment loads than perennial channels because of their abundance and lower vegetative cover. This study examines above- and belowground standing crop responses of selected vegetation classes and density of shrubs to grazing use and yearly weather variation along an ephemeral stream in northcentral Wyoming.

Aboveground biomass standing crop was determined yearly in channel, floodplain, and upland habitats in ungrazed and grazed pastures during the 4-year study. Belowground biomass and shrub densities were determined yearly in the channel habitat only.

Perennial grass standing crop in channels did not respond to grazing but decreased up to $73 \%$ with decreases in frequency and amount of precipitation. In floodplains, perennial grasses were not responsive to grazing; annual grasses were twice as abundant in grazed pastures. Vegetation standing crop in uplands was not influenced by grazing. Over the study period in all pastures, standing crop of blue grama (Bouteloua gracilis (H.B.K.) Lag. ex Griffiths) declined 4 fold while cool-season grasses increased 5 fold. Shrub density did not increase as much in grazed as in ungrazed pastures. Root biomass of the channel decreased $23 \%$ in years with less precipitation but was greater by $24 \%$ on concave than convex bank types. Location on channels influenced root biomass but grazing did not. Lack of general negative grazing influences on vegetation suggest short periods ( 10 days) of grazing as used in this study represent a sustainable management alternative for grazing in the cold desert.

Key Words: grazing, weather, aboveground biomass, shrub density, belowground biomass, channel morphology

Understanding impacts of large herbivore grazing on vegetation is critical in developing rangeland management plans. This is especially true for the plant communities associated with streams traversing arid and semiarid rangelands. Reviews by Platts (1982a, 1982b), Skovlin (1984), and Kauffman and Krueger (1984) and reports like U.S. GAO (1988) and Chaney et al. (1990) identify the importance of riparian zones for multiple uses. They focus on livestock grazing effects on perennial stream systems. Several investigators have reported on impacts of various livestock grazing management strategies on vegetation, channel integrity, recreation and fishery/wildlife values, and nonpoint pollution on riparian zones of perennial streams (Elmore and Beschta 1987, Platts 1989, Myers 1989, and Clary and Webster 1989). Less is known about ecology and multiple use of streamside zones along ephemeral streams.

Published as journal article JA 1630 of the Wyoming Agricultural Experiment Station.

This work was supported by Wyoming Department of Environmental Quality, Wyoming Water Research Center, and Bureau of Land Management.

Manuscript accepted 13 July 1992.
Swanson et al.'s (1988) classification of riparian areas notes that the U.S. Bureau of Land Management's (1987) riparian zone policy excludes ephemeral streams or washes that do not exhibit the presence of vegetation dependent upon free water in the soil. Ephemeral streams, arroyos, washes, and gullies within semiarid lands can be sources of excessive sediment in perennial stream flow (Graf 1985). Cooke and Reeves (1976) attribute formation of arroyos in the U.S. Southwest and accelerated erosion to climatic effects triggered by road and trail development, and livestock grazing.

Although ephemeral streams carry only periodic flow, riparian plant species often occupy floodplain space due to hydraulic disturbance (Pickett 1980, Szaro 1990) and a subsurface water table. Riparian plants contribute to structural diversity of habitats and can be used to indicate where watershed improvement practices can supplement baseflow from streambanks and alluvium within ephemeral and intermittent channels. Baseflow augmentation is reviewed by Ponce and Lindquist (1990). Examples of changing streamflow from ephemeral to perennial are described by Heede (1977), Hooper et al. (1987), and Elmore and Beschta (1987). Watershed improvements to augment base flow are often associated with instream structures but structures are not always needed nor desirable.

Elmore and Beschta (1987) emphasize that instream improvements should not replace sound management of livestock grazing. Van Haveren and Jackson (1986) note that geomorphological processes will naturally heal riparian zones if watersheds are managed in a sound manner and time is not limiting. Van Haveren and Jackson (1986) pose 3 questions to be answered before using structures for modifying stream conditions: "i) will the structure permit the system to reach a condition of natural stability more rapidly than can be achieved passively? ii) are the benefits achieved by accelerated rehabilitation sufficient to justify the costs? and iii) will the achieved condition be self-sustaining, or will it be dependent upon the integrity of the structure? In most cases, the answer to all 3 questions should be yes".

The purpose of our overall study was to evaluate the potential of controlled livestock grazing to improve channel condition for baseflow augmentation on an ephemeral stream. We felt that controlled grazing should improve streambank vegetation cover, allowing more sediment to be deposited, thus raising the stream bottom at least as well or rapidly as no grazing. The ephemeral stream studied has isolated pockets of plains cottonwood ( Populus deltoides Bartr. ex Marsh.) and coyote willow (Salix exigua Nutt.) along its floodplain and incised channel suggesting that the subsurface moisture already present could be enhanced by channel management. We evaluated cattle habitat selection and forage utilization rates (Smith et al. 1989, Smith et al. 1992), grazing and yearly weather effects on vegetation, sediment deposition rates, and channel dynamics. 
This paper reports on the part of our study concerning yearly dynamics of above- and belowground vegetation. Specific points addressed are yearly weather and grazing effects on: (1) Aboveground biomass of selected herbage classes in channel, flood plain and upland habitats, (2) Shrub density in channels on differing bank aspects (exposure to solar radiation), (3) Root biomass in channels on different reaches, reach types, and bank levels above channel floor.

\section{Methods and Materials}

\section{Study Area and Treatments}

The study area consisted of 5 adjacent pastures, each about 30 ha, located on Middle Fork just above its confluence with the South Fork of 15 -Mile Creek. The site was located $15 \mathrm{~km}$ west of Worland, Wyo. The pasture sequence was established to maximize channel and riparian zone restoration through base flow augmentation (Heede 1977, 1982). The downstream pasture was ungrazed and reserved for future placement of structures, if needed, to raise the stream bed level. The pasture furthest upstream was ungrazed in an attempt to enhance growth of channel vegetation and thereby reduce stream flow velocity in the transition from a higher upstream to lower gradient in pastures downstream. The 3 pastures in between were grazed by cattle 1983-1986. Proceeding upstream, pastures were grazed in late May, mid July, and mid September. Thirty cow/calf pairs were placed in each pasture for 10 days to achieve a moderate stocking rate of .33 AUM/ha. Perennial forage species were utilized 25-50\% (Smith et al. 1989 and 1992). Greasewood (Sarcobatus vermiculatus (Hook.) Torrey) was utilized 20-80\% depending on season and plant part. Stockwater was provided in troughs in the flood plain of each pasture.

Precipitation amount and frequency were continuously recorded during the growing season at 3 stations located west to east along the stream course; $20 \mathrm{~km}$ upstream (Squaw Teats), $3 \mathrm{~km}$ upstream (Middle Fork), and at the exclosure. Stream flow gauging for this tributary of 15-Mile Creek were unavailable and personnel were not on site frequently enough to record flow frequency.

Each pasture contained about $.7 \mathrm{~km}$ of channel and included the floodplain and upland. The stream bottom was from 1-2 m across with banks of about $3 \mathrm{~m}$ length, sloping at about a $44^{\circ}$ angle from a nearly level floodplain. Bed materials averaged $58 \%$ sand, $25 \%$ silt, and $17 \%$ clay. We observed that fine sediments in low flows apparently sealed the channel and limited transmission of water into adjacent alluvium. The floodplain was about $100-150 \mathrm{~m}$ wide. The pastures were on a uniformly low gradient (0.03-0.05\% slope) meandering area of the stream, located downstream from a higher gradient $(0.06 \%$ slope), straighter section.

The area is in a 12.5 to $22.5 \mathrm{~cm}$ annual precipitation zone (SCS 1988). The vegetation is generally classified as cold desert shrub; however, the area differs from other cold desert areas of Wyoming and the intermountain west by having a higher frequency of summer precipitation (Fisser 1982), and consequently more warmseason grasses in the flora.

Three habitats were designated within the study area: incised channel, flood plain, and upland. Channel bank vegetation was largely herbaceous with Canada wildrye (Elymus canadensis L.) (all plant names used herein follow Dorn 1988); inland saltgrass (Distichlis stricta (Torrey) Rydb.); and slimflower scurfpea (Psoralea tenuiflora Pursh) as dominant perennials. Annuals, sixweek grass (Festuca octoflora Walt.) and cheatgrass brome (Bromus tectorum L.), were usually present. Big sagebrush (Artemisia tridentata Nutt. var. tridentata) and green and rubber rabbitbrushes (Chrysothammus vicidiflorus (Hook.) Nutt., C.nauseosus (Pallas ex Pursh) Britt.) were common on channel banks.

The flood plain overstory was dominated by big sagebrush and greasewood. The understory vegetation was dominated by annu- als, sixweeks fescue, cheatgrass brome, peppergrass (Lepidium spp.), and plantain ( Plantago spp.). Perennials included rhizomatous wheatgrasses (Elymus spp.), Indian ricegrass (Oryzopsis hymenoides (R. \& S.) Ricker ex Piper), and needleandthread (Stipa comata Trin. \& Rupr.). Plains pricklypear (Opuntia polyacantha Haw.) was common. Plains cottonwood provided occasional relief to the otherwise monotonous flood plain landscape.

Uplands were dominated by blue grama (Bouteloua gracilis (H.B.K.) Lag. ex Griffiths) and plains pricklypear. Other species included needleandthread, Indian ricegrass, rhizomatous wheatgrass, sixweeks grass, and cheatgrass brome.

\section{Sampling}

\section{Soil Water and Water Table Level}

We measured soil water in each pasture using neutron attenuation throughout this study by placing access tubes ( 20 per pasture) near vegetation sampling sites at the edge and 1 and $2 \mathrm{~m}$ from channel edges with the bottom at $3 \mathrm{~m}$ depth near or below the level of the channel floor. Access tubes were also located at mid floodplain and near the outer edge. Observations were made monthly, May to September. We also placed $6 \mathrm{~cm}$ plastic observation wells up to 3 meters below the base level of the channel floor. Free water was not found and regular observations were not continued.

\section{Aboveground Standing Crop}

Current year's peak standing crop of herbaceous biomass was determined yearly in July in channel (1984-1986) and floodplain and upland (1983-1986) sites. This sampling date could have underestimated peak standing crop in the spring grazed pasture; however, noticeable regrowth occurred after grazing and before harvesting because of residual soil moisture. A double sampling procedure was used. Standing crop was estimated by species on permanently located quadrats along transects. Temporary quadrats located $1 \mathrm{~m}$ away from at least one-half of the permanent quadrats and with locations rotated yearly were estimated and then harvested to calculate a regression to adjust estimated standing crops.

Table 1. Total herbaceous vegetation and perennial grass standing crop $\left(\mathrm{g} / \mathrm{m}^{2}\right)$ of channels in pastures on Middle Fork, 15-Mile Creek.

\begin{tabular}{|c|c|c|c|c|}
\hline & \multicolumn{3}{|c|}{ Years } & \multirow[t]{2}{*}{ Mean } \\
\hline & 1984 & 1985 & 1986 & \\
\hline & \multicolumn{4}{|c|}{$\left(\mathrm{g} / \mathrm{m}^{2}\right)$} \\
\hline \multicolumn{5}{|c|}{$\begin{array}{l}\text { Total herbaceous } \\
\text { pasture }\end{array}$} \\
\hline Control 1 & 42 & 36 & 36 & $38 \pm 7.2$ \\
\hline Spring 2 & 31 & 24 & 20 & $25 \pm 5.9$ \\
\hline Summer 3 & 52 & 36 & 35 & $41 \pm 10.9$ \\
\hline Fall 4 & 73 & 24 & 52 & $47 \pm 15.7$ \\
\hline Control 5 & 35 & 27 & 13 & $25 \pm 8.8$ \\
\hline MEAN $^{2}$ & $46 \pm 11.0 a$ & $28 . \pm 6.0 \mathrm{a}$ & $31 \pm 5.2 \mathrm{a}$ & \\
\hline \multicolumn{5}{|c|}{$\begin{array}{l}\text { Perennial grass } \\
\text { pasture }\end{array}$} \\
\hline Control 1 & 28 & 12 & 26 & $22 \pm 5.7$ \\
\hline Spring 2 & 17 & 6 & 13 & $12 \pm 3.2$ \\
\hline Summer 3 & 49 & 9 & 22 & $27 \pm 12.0$ \\
\hline Fall 4 & 23 & 8 & 19 & $17 \pm 4.5$ \\
\hline Control 5 & 34 & 7 & 11 & $17 \pm 8.1$ \\
\hline Mean & $30 \pm 7.8 b$ & $8 \pm 2.3 a$ & $19 \pm 4.2 \mathrm{ab}$ & \\
\hline \multicolumn{5}{|l|}{ Bank levels** } \\
\hline Low & 8 & 19 & 7 & $11 \pm 1.9 \mathrm{a}$ \\
\hline Mid & 22 & 4 & 15 & $14 \pm 2.6 \mathrm{a}$ \\
\hline Top & 61 & 2 & 34 & $32 \pm 8.4 b$ \\
\hline
\end{tabular}

IYear means and main effect means \pm standard error

${ }^{2}$ Means for bank levels (column) and years (row) followed by the same letter were not significantly different $(p \leq .05)$.

* Significant interaction $(p \leq 05)$, bank level $\times$ year. 
In channels, sampling points were located on 5 cross-sections on a representative straight stream reach in each pasture. Quadrats $\left(0.25 \mathrm{~m}^{2}\right)$ were located on both banks at bottom, middle, and top of the bank for a total of 30 ( 10 for each bank level) quadrats estimated and an additional 18 quadrats harvested and estimated in each pasture. Vegetation standing crop was summarized by bank level in each pasture yearly for 2 categories, all herbaceous vegetation and all perennial grasses. Perennial forbs and annual plants were major constituents of the difference between the 2 vegetation categories.

In flood plains, permanent quadrats $\left(0.5 \mathrm{~m}^{2}\right)$ were systematically located on 2 types of transects (those designated short were perpendicular to and within $50 \mathrm{~m}$ of channel and long transects extending beyond short transects to upland edge) extending from channel bank edge to uplands on both sides of the channel from representative straight and meander reaches in each pasture. Each pasture had 60 quadrats estimated and an additional 30 quadrats estimated and harvested. Vegetation standing crop in each pasture was summarized yearly for short and long transects for 2 categories, all herbaceous vegetation and perennial grasses. The difference between the 2 vegetation categories was primarily annual species.

In uplands 1 transect of 10 permanent quadrats $\left(0.5 \mathrm{~m}^{2}\right)$ was randomly located for estimation of biomass. An additional 5 quadrats were estimated and standing crop harvested. Vegetation standing crop was summarized yearly for each pasture for 2 categories, all herbaceous vegetation and blue grama. The difference between the 2 vegetation categories was primarily cool-season grasses.

\section{Shrub Density}

Shrub density on channel banks was determined yearly (1984-1986) in June on 1 meander and 1 straight reach of channel in each study pasture. Sample units (10 per pasturc) were $3.05 \times$ $3.05 \mathrm{~m}$ in area and extended from channel bottoms to top of banks. All big sagebrush, green rabbitbrush, and rubber rabbitbrush plants were counted regardless of size class. Densities were summarized for each species and total shrubs for the 2 reaches in each pasture for south and north aspect banks yearly. Reach summary data were further identified with respect to bank types (concave, convex, and straight) and reach type (straight and meander).

\section{Root Biomass}

Root biomass was sampled at low, middle, and top bank levels on straight and meander reaches on the same 5 cross-sections at each reach as other channel vegetation samples in each of the pastures. A steel tube, $6.35 \mathrm{~cm}$ diameter, was used. Sampling was restricted to the top $15 \mathrm{~cm}$ of soil because extensive preliminary sampling during 1982 indicated roots on the channel banks were evenly distributed by depth to $45 \mathrm{~cm}$. Schreiner (1987) found an even root distribution with depth on building banks being covered with sediment during overflow events of a cold desert perennial stream. Schreiner (1987) speculated that the even distribution of roots by depth on building banks was a result of the plant's continued regrowth of roots in adjustment to continued surface accumulated sediments and wide fluctuations in channel water levels. Sampling only $15 \mathrm{~cm}$ deep satisfied our needs for assessing surface stability of the bank as provided by any potential change in root mass. Duplicate cores were taken at each sample location. Cores were washed in a device patterned after Lauenroth and Whitman (1971). Washed material was subsequently ashed at $500^{\circ}$ C. The material referred to as root biomass is the ash-free fraction of all roots or other organic material and is an index to root mass. Data were summarized yearly for each of the 2 reaches in each pasture by bank level and bank aspect (south and north facing) and further identified as to pasture, bank type (concave, convex, or straight) and reach type (straight or meander). Concomitant measurements of surface soil texture were made from low, mid, and top bank positions. Channel cross section measurements (10 per pasture) evaluated channel filling or cutting before, during, and after the study.

\section{Design and Data Analysis}

The treatment layout consisted of a completely random design with 3 replications of grazing and 2 control replicates. The location of control pastures was deliberate rather than random to encompass the variations possibly existing over the length of the study site and results, we feel, in a more conservative probability of Type 1 error than average (Hurlbert 1984). In this design the best indication of grazing effects are treatment (grazed-non grazed) $\times$ year interactions. Significant interactions are indicative of different kinds or degrees of response over years from grazed compare to nongrazed pasture vegetation (Green 1978). Lines plotting the treatments over years would have a different slope if interactions were significant. Using the interaction to assess grazing effect removes the chance of spurious treatment effect resulting from possible differences between pastures at the outset of the study. The experimental unit for data analysis was yearly pasture mean or

Table 2. Total herbaceous vegetation and perennial grass standing crop $\left(\mathrm{g} / \mathrm{m}^{2}\right)^{1}$ of flood plain habitats in pastures on Middle Fork, 15-Mile Creek.

\begin{tabular}{|c|c|c|c|c|c|}
\hline & \multicolumn{4}{|c|}{ Years } & \multirow[t]{2}{*}{ Mean } \\
\hline & 1983 & 1984 & 1985 & 1986 & \\
\hline & \multicolumn{4}{|c|}{$\left(\mathrm{g} / \mathrm{m}^{2}\right)$} & \\
\hline \multicolumn{6}{|c|}{$\begin{array}{l}\text { Total herbaceous } \\
\text { pasture }\end{array}$} \\
\hline Control 1 & 12 & 14 & 6 & 12 & $11 \pm 2.1$ \\
\hline Spring 2 & 6 & 4 & 8 & 13 & $8 \pm 1.4$ \\
\hline Summer 3 & 14 & 13 & 19 & 27 & $18 \pm 2.5$ \\
\hline Fall 4 & 23 & 10 & 10 & 38 & $20 \pm 5.2$ \\
\hline Control 5 & 22 & 7 & 7 & 21 & $14 \pm 2.9$ \\
\hline MEAN2 & $16 \pm 2.6 \mathrm{ab}$ & $9 \pm 2.0 \mathrm{a}$ & $10 \pm 1.6 \mathrm{a}$ & $22 \pm 3.8 b$ & \\
\hline \multicolumn{6}{|c|}{ Perennial grass } \\
\hline Control 1 & 6 & 5 & 2 & 3 & $4 \pm 0.8$ \\
\hline Spring 2 & 3 & 2 & 2 & 1 & $2 \pm 0.4$ \\
\hline Summer 3 & 6 & 3 & 3 & 4 & $4 \pm 0.7$ \\
\hline Fall 4 & 3 & 4 & 3 & 6 & $4 \pm 0.9$ \\
\hline Control 5 & 8 & 3 & 3 & 6 & $5 \pm 0.9$ \\
\hline MEAN & $5 \pm 0.7 a$ & $3 \pm 0.6 \mathrm{ab}$ & $2 \pm 0.3 b$ & $4 \pm 0.9 \mathrm{ab}$ & \\
\hline
\end{tabular}

'Year means and main effect means \pm standard error.

2 Means for years (rows) followed by the same letter were not significantly different $(p \leq .05)$. 


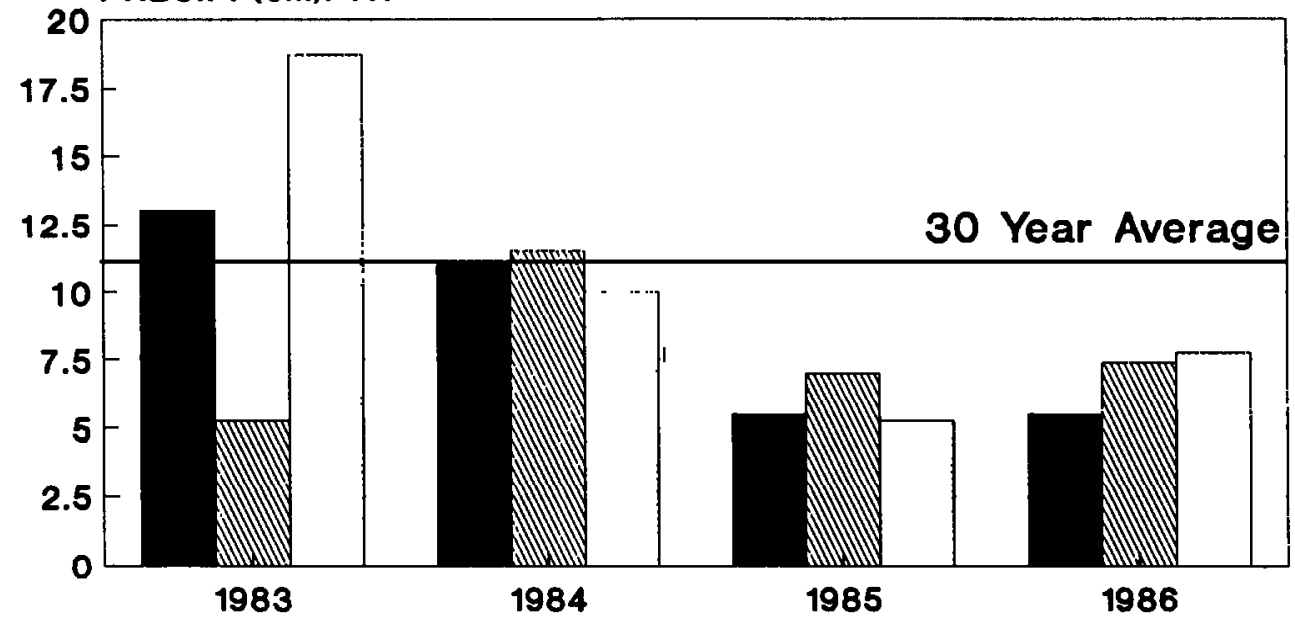

Locations:

\section{Exclosure Middle Fork Squaw Teats}

Fig. 1. Precipitation amount 1983-1986 for Middle Fork, 15-Mile Creek watershed, and 30-year average for Worland, May-September.

pasture mean of subcategories such as reach type or bank level.

The data analysis software was SAS (Freund et al. 1986). Repeated measures with $\mathrm{H}-\mathrm{F}$ adjustment (years repeated) analysis of variance procedures were used. Duncan's multiple range test was used when significant differences occurred to separate means. A Type I error probability of $P \leq 0.05$ was used. Analysis for aboveground biomass was a factorial $(4 \times 2$ for upland, $4 \times 2 \times 2$ for floodplain, $3 \times 2 \times 3$ for channel; factors: years, grazing-no grazing, transects (short-long for flood plain only), and bank level (lowmiddle-top for channel only). Shrubs were analysed with a $3 \times 2 \times 3 \times 2$ factorial; factors: years, grazing-no grazing, bank type (concave-convex-straight) and bank aspect (south-north). Root biomass analysis was a $3 \times 2 \times 3 \times 2 \times 3 \times 10$ factorial; factors were the same as for shrubs with the addition of bank levels (low-middletop), and reaches (1-10). Root biomass of straight, convex, and concave bank types were analysed separately with a $3 \times 2 \times 2 \times 3 \times 5$ factorial; factors were years, grazing treatment, bank aspect (omitted for concave and convex banks), bank levels, and reaches.
Analyses included two-day interactions among factors. Three-way or higher interactions were not evaluated.

\section{Results and Discussion}

\section{Aboveground Standing Crop}

\section{Channel}

Total herbaceous vegetation biomass of channels did not significantly vary with years, grazing treatment, or bank level. Interactions were not apparent (Table 1).

Perennial grass varied in response to years and bank level interaction but was not affected by grazing treatment. Perennial grass standing crop on the top bank was highest in 1984, generally the wettest of the 3 years; intermediate in 1986, with a similar number of precipitation events to 1984 , but less precipitation; and lowest in 1985 , with lowest number of events and precipitation amount in the growing season (Table 1, Figs. 1 and 2). Less standing crop than top bank on mid and low banks may have been due to bank disturbance and sediment deposition over vegetation by flow

NUM. EVENTS/YR

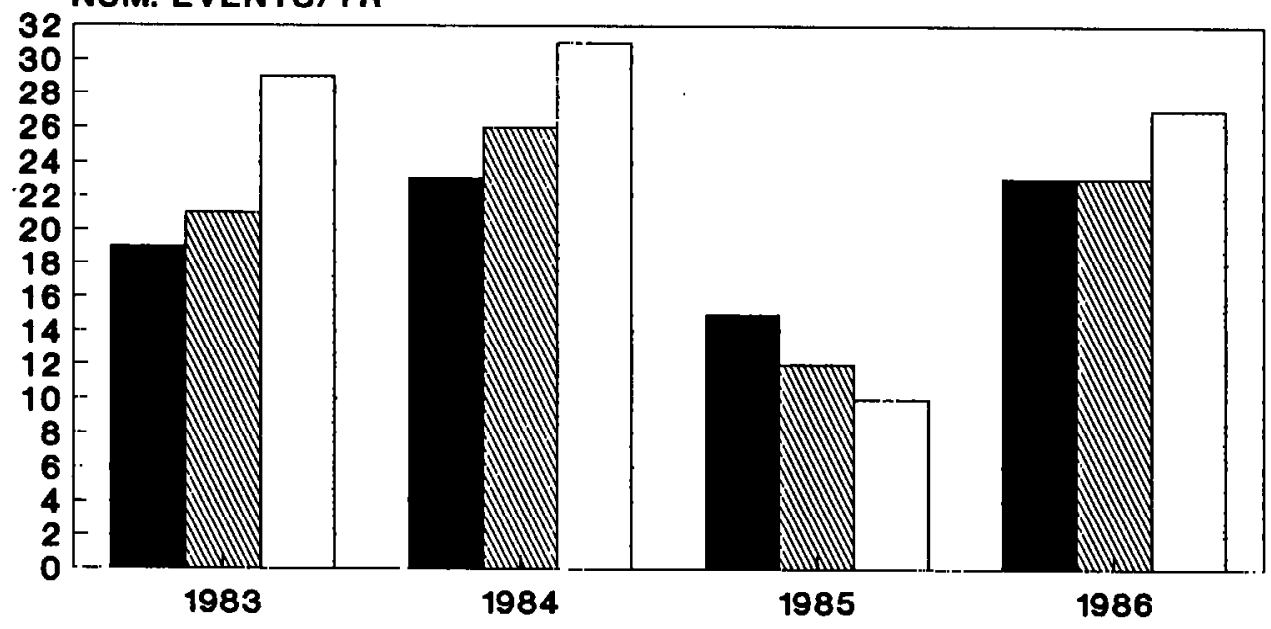

Locations:

Exclosure Middle Fork $\square$ Squaw Teats

Fig. 2. Precipitation frequency for Middle Fork, 15-Mile Creek watershed, May-September, 1983-1986.

JOURNAL OF RANGE MANAGEMENT 46(1), January 1993 

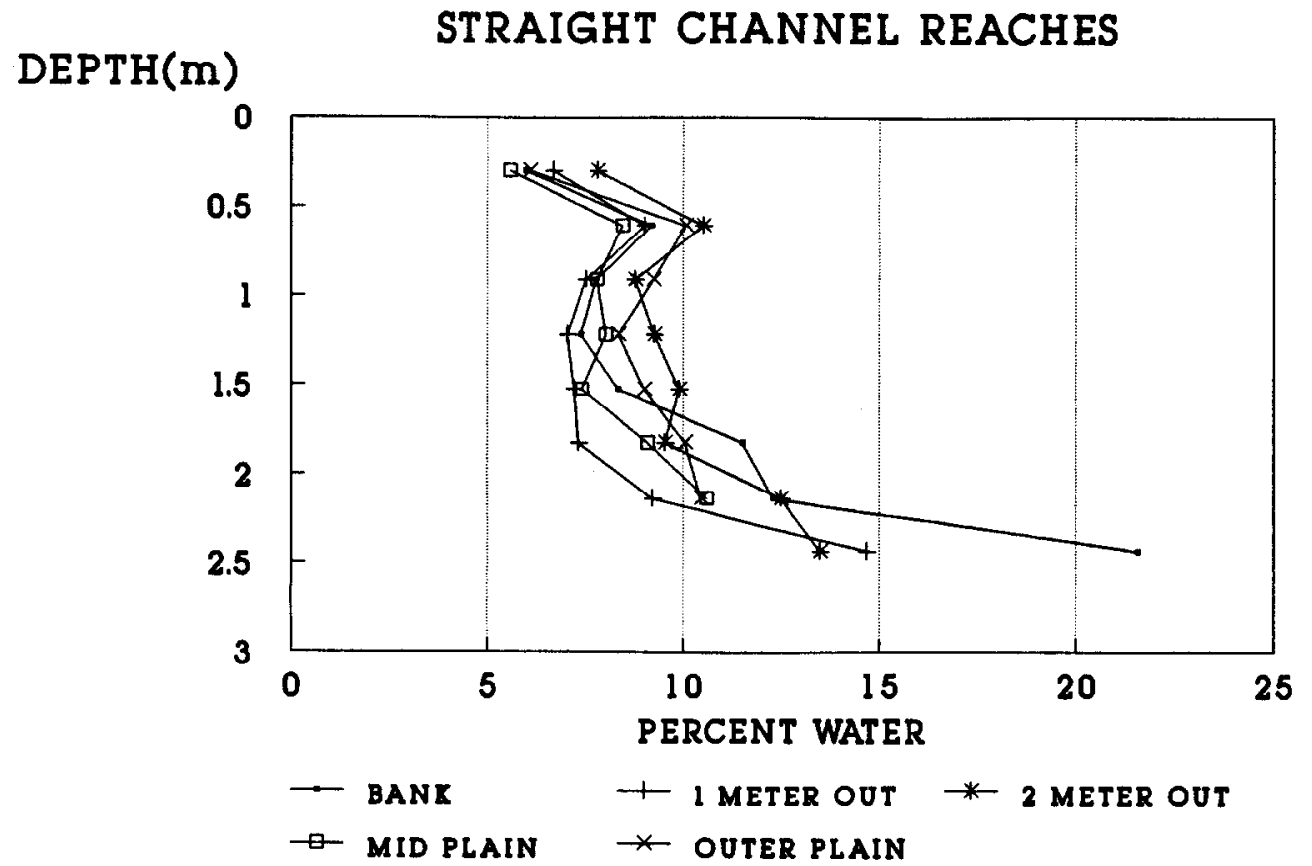

Fig. 3. Soil water content (\% volume, mean of all seasons and years) at depths from floodplain surface and distances from the channel edge along $15-M i l e$ Creek, 1983-1986.

events. Even though flow events commonly do not reach the top bank level, they may wet the root zone of plants of that position.

Significant bank level by year interaction with perennial grasses (Table 1) seemed to relate to precipitation frequency and amount. Highest standing crop on low bank and lowest standing crop on mid and top bank positions occurred in 1985 coincident with fewer precipitation events (Fig. 2) and somewhat lower precipitation than other years (Fig. 1) in contrast to the general trends in bank level and yearly standing crop. Reversal of trends in standing crop in 1985 may be due to less vegetation disturbance on the low bank by fewer stream flows coupled with less available moisture for plants on mid and top bank positions. Fewer events and lesser amounts of precipitation as in 1985 indicate a lower probability of streamflow from the large watershed contributing area to the narrow valley confines of the study area (Branson et al. 1981).

We observed no water recharge to the floodplains through channel banks after flow events but the neutron probe monitoring schedule never coincided with a flow event. Our neutron probe monitoring of soil water indicated no difference in soil water between positions located closer to the bank and those distant into the floodplain (Fig. 3). We conclude that the stream reach flowing through the study site is a perched stream, well above any watertable. Groundwater was observed in only one well above the upstream exclosure where outcrops of shale and sandstone occur along the narrows of the upstream valley.

We suggest that soil conditions on the channel floor and low bank, reached by most flow events, may more readily promote channel transmission loss vertically through the channel bottom than into bank slopes. The bottom of the channel is predominantly sand. Visual observations during all years showed that sand under the first few centimeters of the channel was moist during the growing season. In contrast, clay content is greater on the lower slope of the channel banks. The top of the slope is mostly sand.

Boelman (1989) studied surface/groundwater interactions on a cold desert perennial stream in Wyoming and found stream channels sealed by clay so water recharge to adjoining banks and through the channel bottom did not occur. Kraeger-Rovey (1991) also attributed channel sealing and retarded aquifer recharge to fine sized soil particles interspersed with larger gravels deposited in horizontal lenses and suggested that these layers restricting flow may be formed by hydraulic discontinuity in streamflow or in place deposition of sediments. Minimal water movement into banks indicates that channel flow events represent a small supplement to local precipitation. Thus plant species on channel banks and adjacent floodplains would be limited to species only marginally different in water requirements from upland species except for those species like cottonwood able to exploit deep water sources.

\section{Flood Plains}

Total herbaceous standing crop and the perennial grasses component significantly varied with years of study (Table 2) but was not influenced by grazing treatment, transect type, or interactions. Annual variation in standing crop was only partially associated with summer precipitation amount (Fig. 1) and frequency (Fig. 2). The remainder of the variability was likely due to the influence of fall/winter precipitation and seasonal temperatures on germination and growth of annuals (represented by difference between herbaceous and perennial categories). The lack of graze-ungrazed $X$ year interaction indicated no effect of grazing.

\section{Uplands}

Upland vegetation standing crop (Table 3) varied among years of study but not grazing treatment. Interaction of years with grazing treatment was not significant. The almost yearly decrease in standing crop of blue grama was somewhat associated with growing season precipitation amount (Table 3, Fig. 1). Herbaceous vegetation in contrast followed a similar pattern as flood plains herbaceous standing crop by increasing (although not significantly) in 1986 compared to 1984-1985. The difference in trend over years between all herbaceous and blue grama categories (annuals were a minor component of upland vegetation) in uplands suggests an increase in cool-season perennial grasses regardless of grazing or nonuse. Grazing in this study may represent a reduction of pressure from the season long grazing of the past and allowed cool-season grasses to increase. In addition the relatively low summer precipitation would have been unfavorable for blue grama. 
Table 3. Total herbaceous vegetation and blue grame standing crop $\left(g / \mathrm{m}^{2}\right)^{1}$ of upland habitats in pastures on Middle Fork, 15-Mile Creek.

\begin{tabular}{|c|c|c|c|c|c|}
\hline & \multicolumn{4}{|c|}{ Years } & \multirow[t]{2}{*}{ Mean } \\
\hline & 1983 & 1984 & 1985 & 1986 & \\
\hline & \multicolumn{4}{|c|}{$\left(\mathrm{g} / \mathrm{m}^{2}\right)$} & \\
\hline \multicolumn{6}{|c|}{$\begin{array}{l}\text { Total herbaceous } \\
\text { pasture }\end{array}$} \\
\hline Control 1 & 21 & 11 & 11 & 11 & $14 \pm 2.6$ \\
\hline Spring 2 & 29 & 13 & 16 & 27 & $21 \pm 4.0$ \\
\hline Summer 3 & 24 & 22 & 15 & 42 & $26 \pm 6.4$ \\
\hline Fall 4 & 23 & 16 & 10 & 11 & $15 \pm 3.0$ \\
\hline Control 5 & & & 10 & 12 & $13 \pm 2.8$ \\
\hline MEAN $^{2}$ & $24 \pm 1.4 a$ & $14 \pm 2.3 b$ & $12 \pm 1.2 b$ & $21 \pm 6.7 \mathrm{ab}$ & \\
\hline \multicolumn{6}{|l|}{$\begin{array}{l}\text { Blue grama } \\
\text { pasture }\end{array}$} \\
\hline Control 1 & 19 & 11 & 11 & 1 & $10 \pm 3.8$ \\
\hline Spring 2 & 26 & 12 & 12 & 2 & $13 \pm 5.0$ \\
\hline Summer 3 & 19 & 12 & 13 & 12 & $13 \pm 1.7$ \\
\hline Fall 4 & 22 & 12 & 9 & 5 & $12 \pm 3.6$ \\
\hline Control 5 & 21 & & 10 & 8 & $12 \pm 3.0$ \\
\hline MEAN & $21 \pm 1.3 \mathrm{a}$ & $11 \pm 0.6 \mathrm{~b}$ & $11 \pm 0.8 b$ & $5 \pm 2.1 c$ & \\
\hline
\end{tabular}

'Year means and main effect means \pm standard error.

2Means for years (rows) followed by the same letter were not significantly different $(p \leq 0.05)$.

\section{Shrub Density}

Shrub counts were dominated by seedlings and thus do not necessarily represent dominance relationships among species. These data may be more representative of reproductive potential. Unfortunately, we cannot partition seedlings from nonseedlings in our data set. All shrubs and each species varied among years. Grazing treatment main effect influenced only rubber rabbitbrush, but year $\times$ grazing treatment interaction influenced both green and rubber rabbitbrush. Bank type was not significant for any shrub. Bank aspect and year $\times$ bank aspect interaction significantly influenced all shrubs, big sagebrush, and green rabbitbrush.

Big sagebrush and green rabbitbrush densities were lowest in 1985, intermediate in 1984 and greatest in 1986 (Table 4) but

Table 4. Shrub density (plants $\left./ 9.3 \mathrm{~m}^{2}\right)^{1}$ of channels in pastures on Middle Fork, 15-Mile Creek.

\begin{tabular}{lccc}
\hline \hline & \multicolumn{3}{c}{ Years } \\
\cline { 2 - 4 } & \multicolumn{3}{c}{ (plants $/ 9.3 \mathrm{~m}^{2}$ ) } \\
\hline $\begin{array}{l}\text { All shrubs } \\
\text { MEAN }\end{array}$ & $67 \pm 4.3$ & $33 \pm 2.7 \mathrm{a}$ & $98 \pm 14 . \mathrm{c}$ \\
$\begin{array}{l}\text { Big sagebrush } \\
\text { MEAN }\end{array}$ & $18 \pm 1.8 \mathrm{a}$ & $9 \pm 1.1 \mathrm{a}$ & $64 \pm 13.5 \mathrm{~b}$ \\
$\begin{array}{l}\text { Green Rabbitbrush } \\
\text { MEAN }\end{array}$ & $27 \pm 4.5 \mathrm{ab}$ & $22 \pm 2.3 \mathrm{a}$ & $31 \pm 2.8 \mathrm{~b}$ \\
$\begin{array}{l}\text { Rubber Rabbitbrush } \\
\text { MEAN }\end{array}$ & $21 \pm 3.7 \mathrm{a}$ & $2 \pm 0.4 \mathrm{~b}$ & $3 \pm 0.5 \mathrm{~b}$ \\
\hline
\end{tabular}

${ }_{1}$ Year means and main effect means \pm standard error.

${ }^{2}$ Means for years (rows) followed by the same letter were not significantly different $(p \leq 0.05)$.

numbers were apparently not closely related to amount or frequency of precipitation in those years. Unfortunately, distribution of precipitation events for winter and spring months for the site is not available. Rubber rabbitbrush was less abundant in 1985-1986 than in 1984 and therefore seemed positively associated with precipitation (Fig. 1 and 2).

Cattle grazing activity (soil disturbance, trampling, or consumption) appeared to cause green rabbitbrush amounts to decline (Table 5) in grazed pastures while increases occurred in ungrazed pastures from 1984 to 1986 . Green rabbitbrush in the grazed pastures also did not respond similarly to yearly precipitation as that
Table 5. Green and rubber rabbitbrush denstity (plants $\left./ 9.3 \mathrm{~m}^{2}\right)^{1}$ on channel banks in pastures on Middle fork, 15-Mile Creek.

\begin{tabular}{lllll}
\hline & \multicolumn{4}{c}{ Years } \\
\cline { 2 - 5 } & 1984 & 1985 & 1986 & MEAN2 \\
\hline Green rabbit- & & \multicolumn{3}{c}{ (plants $/ 9.3 \mathrm{~m}^{2}$ ) } \\
brush pastures** & & & & \\
$\quad$ Control (1) & 17 & 23 & 41 & $27 \pm 3.7 \mathrm{a}$ \\
Grazed (2,3,4) & 34 & 19 & 25 & $26 \pm 2.8 \mathrm{a}$ \\
Control (5) & 20 & 31 & 38 & $29 \pm 3.9 \mathrm{a}$ \\
MEAN & $27 \pm 4.5 \mathrm{ab}$ & $22 \pm 2.3 \mathrm{a}$ & $31 \pm 2.8 \mathrm{~b}$ & \\
Rubber rabbit- & & & & \\
brush pastures** & & & & \\
Control (1) & 39 & 2 & 5 & $15 \pm 5.4 \mathrm{a}$ \\
Grazed (2,3,4) & 15 & 2 & 2 & $6 \pm 1.7 \mathrm{~b}$ \\
Control (5) & 23 & 2 & 3 & $9 \pm 3.6 \mathrm{ab}$ \\
Mean & $21 \pm 3.7 \mathrm{a}$ & $2 \pm 0.4 \mathrm{~b}$ & $3 \pm 0.5 \mathrm{~b}$ & \\
\hline
\end{tabular}

1 Year means and main effect means \pm standard error.

2Means for grazed-non grazed (column) and years (rows) followed by the same letter were not significantly different $(p \leq 0.05)$.

**Significant interaction $(p \leq 05)$, year and grazed-non grazed pastures.

in ungrazed pastures. Rubber rabbitbrush was more numerous in ungrazed pastures during the higher precipitation year, 1984, but declined in all pastures in drier years, 1985-1986.

Bank aspect influenced shrub density. Solar radiation subsequently affects soil surface temperatures and moisture. South facing banks, with greater exposure to solar radiation, should have had snow melted and soils warmed sooner in spring, providing germination sites while surface moisture levels were relatively high. This and low flow events that do not recharge upper bank slopes laterally would make winter and spring soil moisture recharge even more important as a yearly water supply for plants. The north facing bank would have had more snow accumulation and later melting. All shrub classes except rubber rabbitbrush had greater numbers (Table 6) on the south facing bank. Significant bank aspect $X$ year interactions for all shrubs, big sagebrush and green rabbitbrush (Table 6) indicated that fluctuations in yearly numbers of plants were much greater on the south facing banks. This is expected because temperature and moisture regimes necessary for 
Table 6. Shrub density (plants $/ 9.3 \mathrm{~m}^{2}$ ) of channel bank aspects (north or south facing) in pastures on Middle Fork, 15-Mile Creek.

\begin{tabular}{|c|c|c|c|c|}
\hline \multirow[b]{2}{*}{ Shrub species } & \multicolumn{4}{|c|}{ Years } \\
\hline & 1984 & 1985 & 1986 & MEAN2 \\
\hline Bank Aspect & \multicolumn{4}{|c|}{ (plants $/ 9.3 \mathrm{~m}^{2}$ ) } \\
\hline All $* *$ & & & & \\
\hline South & 73 & 35 & 139 & $82 \pm 10.8 a$ \\
\hline North & 60 & 32 & 57 & $50 \pm 3.3 b$ \\
\hline MEAN & $67 \pm 4.3 b$ & $33 \pm 2.7 \mathrm{a}$ & $98 \pm 14.2 c$ & \\
\hline \multicolumn{5}{|c|}{ Big sagebrush** } \\
\hline South & 17 & 9 & 101 & $42 \pm 10.3 a$ \\
\hline North & 19 & 10 & 26 & $19 \pm 1.9 b$ \\
\hline MEAN & $18 \pm 1.8 \mathrm{a}$ & $9 \pm 1.1 \mathrm{a}$ & $64 \pm 13.5 b$ & \\
\hline \multicolumn{5}{|l|}{$\begin{array}{c}\text { Green rabbit- } \\
\text { brush** }\end{array}$} \\
\hline South & 38 & 24 & 34 & $32 \pm 3.1 a$ \\
\hline North & 17 & 20 & 27 & $21 \pm 1.9 \mathrm{~b}$ \\
\hline MEAN & $27 \pm 4.5 \mathrm{ab}$ & $22 \pm 2.3 a$ & $31 \pm 2.8 b$ & \\
\hline \multicolumn{5}{|l|}{$\begin{array}{l}\text { Rubber rabbit- } \\
\text { brush }\end{array}$} \\
\hline South & 18 & 2 & 3 & $8 \pm 2.3 a$ \\
\hline North & 24 & 2 & 3 & $10 \pm 2.4 a$ \\
\hline MEAN & $21 \pm 3.7 b$ & $2 \pm 0.4 a$ & $3 \pm 0.5 a$ & \\
\hline
\end{tabular}

1 Means and main effect means \pm standard error

2Means for aspects (column) and years (rows) followed by the same letter were not significantly different $(p \leq .05)$

**Significant interaction ( $p \leq .05)$, between years and bank aspect.

germination and growth of plants are more variable on this aspect.

\section{Root Biomass}

Belowground biomass over all bank types (Table 7) was significantly influenced by year effects, bank type, bank level, reach location, and reach $\times$ bank aspect interaction but not by grazing, bank aspect, or other interactions. Straight bank type root biomass

Table 7. Root biomass $\left(\mathrm{g} / \mathrm{m}^{2}\right)^{1}$ in surface $15 \mathrm{~cm}$ of soils of channel banks in pastures on Middle Fork, 15-Mile Creek.

\begin{tabular}{ll}
\hline \hline & $\left(\mathrm{g} / \mathrm{m}^{2}\right)$ \\
\hline a. & Years \\
1984 & $423 \pm 32 \mathrm{a}^{2}$ \\
1985 & $361 \pm 19 \mathrm{ab}$ \\
1986 & $324 \pm 30 \mathrm{~b}$ \\
b. Pastures & \\
Control $(1,5)$ & $386 \pm 36 \mathrm{a}$ \\
Grazed $(2,3,4)$ & $358 \pm 20 \mathrm{a}$ \\
c. Bank type & \\
concave & $419 \pm 38 \mathrm{a}$ \\
convex & $318 \pm 32 \mathrm{~b}$ \\
straight & $371 \pm 21 \mathrm{ab}$ \\
\hline
\end{tabular}

1 Mean and main effect means \pm standard error.

2Means for years, pastures, or bank type (columns) followed by the same letter were not significantly different $(p \leq 0.05)$.

${ }^{3}$ Pastures were 1, downstream control, 2, spring grazed, 3, summer grazed, 4, fall grazed, and 5, upstream control.

(Table 8 a-d) was affected by years, bank levels, and reaches but not by other factors or interactions. Convex bank type root biomass (Table 8) was affected by years only. Concave bank type root biomass was not affected by any factor analysed.

Biomass of roots and other similar sized organic matter in channel bank soils increases bank stability and provides resistance to erosion during flow events (Whitlow and Harris 1979, Stevens and Waring 1985, Bohn 1989, Henszey et al. 1989). Belowground biomass of all bank types decreased by $23 \%$ from 1984 to 1986 (Table 7a and 8), regardless of grazing (Table $7 b$ ), in a period of decline in growing season precipitation of about $25 \%$ (Fig. 1). The
Table 8. Root blomass $\left(\mathrm{g} / \mathrm{m}^{2}\right)^{1}$ in surface $15 \mathrm{~cm}$ of soils of straight and convex channel banks in pastures on Middle Fork, 15-Mile Creek.

$\left(\mathrm{g} / \mathrm{m}^{2}\right)$

Straight banks

a. Years

$1984 \quad 431 \pm 41 b^{2}$

$1985 \quad 376 \pm 25 \mathrm{ab}$

$1986 \quad 305 \pm 36 a$

b. Pastures ${ }^{3}$

Control $(1,5) \quad 413 \pm 50 \mathrm{a}$

Grazed $(2,3,4) \quad 342 \pm 21 \mathrm{a}$

c. Bank level

Low $378 \pm 30 \mathrm{ab}$

Middle $\quad 426 \pm 37 \mathrm{~b}$

Top $\quad 307 \pm 37 a$

d. Reach number in (pasture ${ }^{3}$ )

2(1)

$4(2)$

$545 \pm 50 \mathrm{c}$

$6(3)$

8(4)

$419 \pm 40 \mathrm{~b}$

$353 \pm 25 b a$

$256 \pm 32 \mathrm{a}$

$10(5)$

$281 \pm 47 \mathrm{a}$

Convex banks

Years

1984

$1985 \quad 316 \pm 36 \mathrm{ab}$

$1986 \quad 220 \pm 28 a$

1 Main effect means \pm standard error.

${ }^{2}$ Means for years grazed-non grazed pastures, bank level, and reaches followed by the same letter were not significantly different $(p \leq 0.05)$. Means are not shown for factors (except grazing) where differences between levels were not significant.

${ }^{3}$ Pastures were 1 , downstream control, 2, spring grazed, 3, summer grazed, 4 , fall grazed, and 5, upstream control.

declines suggest a relatively strong, positive relationship between belowground biomass and precipitation. A reduction in precipitation could have reduced moisture available for growth generally and additionally increased sediment deposition on the low bank position through reducing flow velocity in smaller flow events; however, cross section measurements do not indicate any major sediment deposition during the period (Fig. 4). Small additions of sediment were evident when nails and other transect markers on the low bank were covered. Increased sediment would result in the appearance of a decrease in roots as only the top $15 \mathrm{~cm}$ were sampled. Roots in concave banks however did not change over years as did the straight (Table 8a) and convex bank type (Table 8).

Concave banks had the highest biomass of the 3 types (Table 7c) while convex banks had the least. If bank erosion does not occur and a meander remains stable, the concave bank has the deepest point in the thalweg and the point of last deposition of fine sediment as flow diminishes (Andrews 1982). Because this stream is ephemeral, the last flowing or ponding of water would occur on the outside bend of meanders. The meander pool has a likelihood of being sealed and loss of the water to the aquifer would be slow (Boelman 1989). Last flowing or ponded water along the deepest reach of the thalweg could benefit growing vegetation along the concave curve of meander low banks. During higher flows, sediments are removed from the concave pool and deposited on the convex banks (Leopold and Langbein 1966). The convex bank, inside the meander bend, would receive the least amount and uniformity of water for plant growth. In addition convex banks receive the greatest sediment deposition during flow events thus continually covering roots to a deeper depth.

Root distribution on straight reaches varied with bank level. The middle bank level had root abundance significantly greater than top bank but similar to low bank level (Table 8c). This effect may be due to differential frequencies of wetting. The lower bank levels undoubtedly are wetted more frequently than the top bank posi- 


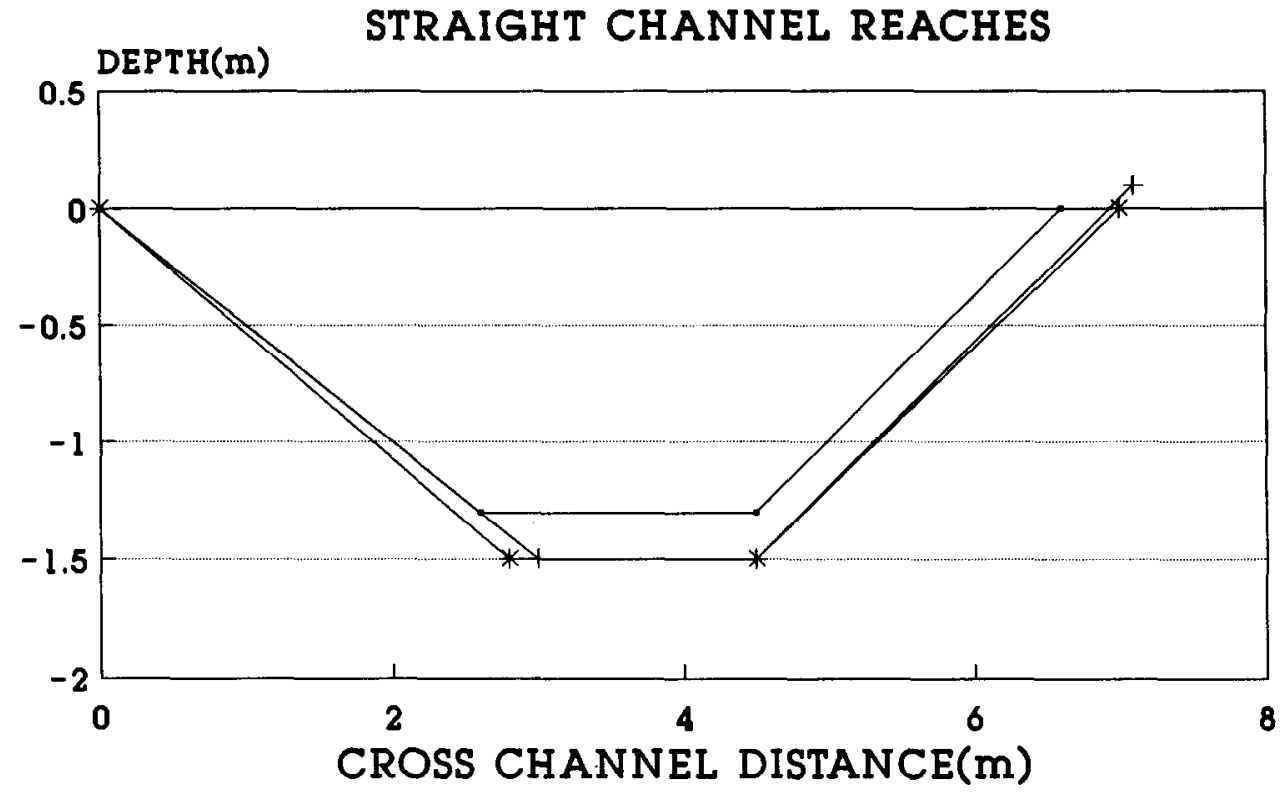

$1982 \rightarrow 1984 \rightarrow 1987$

Fig. 4. Channel profile of straight reaches before, during, and after grazing of 15-Mile Creek.

tion. Middle bank vegetation roots have less distance to grow to tap low bank water supplies than top bank plants during low flow events. Middle bank plants are also closer to the wetted channel perimeter during low flows and can take advantage of the minimal lateral flow of soil water.

Low banks trapped sediments in the band of upright Canada wildrye growing near the channel bottom and were subject to more frequent small flows. The mid bank position vegetation was dominated by inland saltgrass and because of its low growth form may offer less resistance to flow and low ability to trap sediment. The top bank level had more shrubs and upright perennial grasses and was near the height where banks cease to confine high flow events. Because of water spreading into flood plains and resultant decreases in flow velocity during high flow events, large amounts of sediment can be deposited at the junction of top bank and flood plain. Overbank flow events that could have deposited sediment on the top bank and floodplain occurred only twice during study years, both before 1984 .

We found no evidence that grazing influenced belowground biomass in the course of our study (Tables $7 \mathrm{~b}$ and $8 \mathrm{~b}$ ). Comparison of straight reaches (Table 8d) indicates the general decline in belowground biomass progressively upstream from the downstream control pasture (1). The upper pasture is located in the stream gradient transition zone just below a valley constriction. An adjustment in flow dynamics is being made from $0.06 \%$ to $0.03 \%$ stream gradient through the study area. Deposition of sediments generally occurs as flow velocity decreases with gradient. Deposited sediments should decrease and be finer textured further downstream from the transition area. However, no differences in cross section area of the channels or soil texture occurred to support this hypothesis (Fig. 4).

\section{Conclusions}

Grazing at the rates and seasons used in this study appeared to be unimportant to vegetation dynamics of the ephemeral channels. Relatively moderate utilization levels (Smith et al. 1989 and 1992) during the years of grazing treatments did not suggest negative changes should occur. Vegetation dynamics above- and belowground appeared to be mainly a function of yearly fluctuation in moisture regimes and locations in and along the channel. Aboveground biomass and belowground biomass decreased with decreasing growing season precipitation amount. Shrub density seemed most closely related to precipitation frequency probably through its effect on seedlings of shrubs.

Channel bank level affected both above- and belowground biomass but differently. Aboveground perennial grasses seemed most responsive to possible vegetation removal or covering by low events, being less abundant on middle and low bank. Belowground biomass in contrast had highest abundance on middle and low bank levels perhaps in response to increased water provided by flow events. Possibly faster accretion of sediment on the low and top bank may also tend to decrease belowground biomass in the surface $15 \mathrm{~cm}$ of soil compared to the mid level position. Belowground biomass was reduced at upstream locations in a steep to flatter stream channel gradient change.

Sediment accretion rates in channels did not indicate a great potential for grazing to substantially alter this channel in the short term. For land managers addressing appropriateness of public land uses in the Bighorn Basin and other cold desert areas, a noteworthy aspect of this study is that moderate grazing has not shown detrimental effects on vegetation.

\section{Literature Cited}

Andrews, E.D. 1982. Bank stability and channel width adjustments, East Fork River, Wyoming. Water Resource. Res. 18:1184-92.

Bohn, C. 1989. Management of winter soil temperatures to control streambank erosion. p. 69-71. In: Gresswell, R.E.; B.A. Barton; J.L. Kershner (eds.) Practical approaches to riparian resource management: an educational workshop; May 8-11, 1989. Billings, Mont. USDI BLM.

Chaney, E., W. Elmore, and W.S. Platts, 1990. Livestock grazing on western riparian areas. Produced for US-EPA by Northwest Resource Information Center, Inc., Eagle, Ida.

Branson, F.A., G.F. Gifford, K.G. Renard, and R.F. Hadley. 1981. Rangeland Hydrology, Soc. Range Manage. Denver, Colo. p. 73-110.

Boelman, S.D. 1989. Groundwater modeling of cold desert riparian zones along a stream tributary to the upper Colorado Rjver, Masters Thesis, Civil Engineering, Univ. Wyo., Laramie.

Clary, W.P., and B.F. Webster. 1989. Managing grazing of riparian zones in the intermountain region. USDA Forest Serv. Intermount. Forest and Range Exp. Sta. GTR. INT-263. 
Cooke, R.U., and R.W. Reeves. 1976. Arroyos and environmental change in the American south-west. Clarendon Press. Oxford. 213 p.

Debano, L.F., and L.J.J. Schmidt. 1990. Potential for enhancing riparian habitats in the southwestern United States with watershed practices. Forest Ecol. Manage. 33:385-403.

Dorn, R.D. 1988. Vascular plants of Wyoming. Mountain West Publish., Box 1471, Cheyenne, Wyo. 82003.

Elmore, W., and R.L. Beschta. 1987. Riparian areas: perceptions in management. Rangelands 9:260-265.

Freund, R.J., R.C. Littell, and P.C. Spector. 1986. SAS system for linear models. SAS Institute Inc. Cary, N.C.

Fisser, H.G. 1982. Vegetation response to grazing management strategies on semiarid shrublands of Wyoming. p. 162-165. In: D.D. Briske and M.M. Kothman (eds.) Proc. Nat. Conf. on Grazing Techniques. Texas A\&M Univ. College Station. Nov. 10-13.

Graf, W.L. 1985. The Colorado River-instability and basin management. Assoc. Amer. Geograph. Washington, D.C

Green, R.H. 1978. Sampling design and statistical methods for environmental biologists. John Wiley \& Sons. N.Y.

Heede, B.H. 1977. Case study of a watershed rehabilitation project: Alkali Creek, Colorado. USDA Forest Serv. Rocky Mountain Forest and Range Exp. Sta. Ft. Collins, Colo. Res. Paper RM189.

Heede, B.H. 1980. Stream dynamics: an overview for land managers. USDA Forest Serv., Rocky Mountain Forest and Range Exp. Sta. Fort Collins, Colo. Gen Tech. Rep. RM-72.

Heede, B.H. 1982. Gully control: Determining treatment priorities for gullies in a network. Environ. Manage. 6:5441-51.

Henszey, R.J., T.A. Wesche, and Q.D. Skinner. 1989. Evaluation of the state-of-the-art streambank stabilization. Rep. to Wyoming Dep. Environ. Quality, Cheyenne, Wyo.

Hooper, R., B.P. Van Haveren, and W.L. Jackson. 1987. The Sheep Creek Resource Conservation Area Project. Proc., XVIII Conf. Int. Erosion Control Assoc. Reno, Nev. February 26-27, p. 117-126.

Hurlbert, S.H. 1984. Pseudoreplication and the design of field experiments. Ecol. Monog. 54:187-211.

Kauffman, J.B., and W.C. Krueger. 1984. Livestock impacts on riparian ecosystems and streamside management implications...A review. J. Range Manage. 37:430-437.

Kraeger-Rovey, C. 1991. Studies of surface and ground water interactions in two Arizona stream systems. p. 415-424. In: Proc. Colorado Water Engineering and Manage. Conf. February 27-28, Colo. Water Resourc. Res. Inst. and Office of State Engineer, Denver, Colo.

Lauenroth, W.K., and W.C. Whitman. 1971. A rapid method for washing roots. J. Range Manage. 34:308-309.

Leopold, L.B., and W.B. Langbein. 1966. River meanders. The physics of everyday phenomena. Sci. Amer. 214:60-70.

Myers, L.H. 1989. Grazing and riparian management in southwestern Montana. p. 117-120. In: Gresswell, R.E.; B.A. Barton; J.L. Kershner (eds.) Practical approaches to riparian resource management: an educational workshop. May 8-11. Billings, Mont. USDI BLM.

Pickett, S.T.A. 1980. Non-equilibrium coexistence of plants. Bull. Torrey Bot. Club. 107:238-248.

Platts, W.S. 1982a. Sheep and cattle grazing strategies on riparian stream environments. p. 251-270. In: J. Peek, (ed.) Wild life-Livestock Relationships Symp. Proc. Univ. Idaho Forest, Wildl, and Range Exp. Sta. Moscow.
Platts, W.S. 1982b. Livestock and riparian fishery interactions: What are the facts? Trans. North Amer. Wildl. Natur. Resources Conf. 47:507-515.

Platts, W.S. 1989. Compatibility of livestock grazing strategies with fisheries. p. 103-110. In: Gresswell, R.E.; Barton; J.L. Kershner (eds.). Practical approaches to riparian resource management: an educational workshop; May 8-11, Billings, Mont. USDI BLM.

Ponce, V.M., and D.S. Lindquist. 1990. Management of baseflow augmentation: a review. Water Resources Bull. 26:259-268.

Schreiner, T.A. 1987. Characterization of root biomass and soil moisture in riparian zones of southeastern Wyoming. Masters Thesis. Range Manage. Dep. Univ. of Wyoming, Laramie.

SCS. 1988. Technical guide, section IIB, major land resource area (32), 5-9" Big Horn Basin (5-9 BH). USDA SCS. Casper, Wyo.

Skinner, Q.D., J.L. Dodd, J.D. Rodgers, and M.A. Smith. 1985. Antidesertification of riparian zones and control of nonpoint source pollution. p. 382-386. In: Perspectives on nonpoint source pollution. US-EPA. 440/5-85-001, Office of Water Regulations and Standards, Washington, D.C

Skovlin, J.M.1984. Impacts of grazing on wetlands and riparian habitat: a review of our knowledge. p. 1001-1003. In: Nat. Acad. Sci./ Nat. Res. Counc. Developing strategies for rangeland management. Westview Press, Boulder, Colo.

Smith, M.A., Q.D. Skinner, J.L. Dodd, J.D. Rodgers, and R.E. Siekert. 1989. Channel and riparian zone responses to cattle grazing along 15Mile Creek, Bighorn Basin, Wyoming. Final Rep. to Wyoming Dep. Environ. Quality. Range Manage. Dept. Univ. Wyoming. Laramie. 82071.

Smith, M.A., J.D. Rodgers, J.L. Dodd, and Q.D. Skinner. 1992. Habitat selection by cattle along an ephemeral channel. J. Range Manage. 45:385-390.

Stevens, L.E., and G.L. Waring. 1985. The effects of prolonged flooding on the riparian plant community in Grand Canyon. p. 81-86. In: J.R. Johnson, C.D. Ziebell, D.R. Patton, P.F. Ffolliott, and R.H. Hamre (tech. coord.) Riparian ecosystems and their management: reconciling conflicting uses. First North Amer. Riparian Conf. 16-18 April, 1985, Tucson, Ariz. USDA Forest Serv. Rocky Mountain Forest Range Exp. Sta. Gen. Tech. Rep. RM 120.

Swanson, S.R., S.L. Miles, and K. Genz. 1988. Classifying rangeland riparian areas: the Nevada task force approach. J. Soil and Water Conserv. 43:259-263.

Szaro, R.C. 1990. Southwestern riparian plant communities: site characteristics, tree species distributions, and size class structures. Forest Ecol. Manage. 33:315-334.

U.S. Bureau of Land Management. 1987. Riparian area management policy. USDI BLM. Washington, D.C.

U.S. General Accounting Office. 1988. Public rangelands: some riparian areas restored but widespread improvement will be slow. Report to Congr. Requestors, GAO/RCED-88-105, Washington, D.C.

Van Haveren, B.P., and W.L. Jackson. 1986. Concepts in stream riparian rehabilitation. Trans. North Amer. Wildl. and Nat. Resources Conf. 51:280-289.

Whitlow, T.H., and R.W. Harris. 1979. Flood tolerance in plants: a stateof-the-art review. USDOD Army Eng. Waterways Exp Sta. CE. Vicksburg, Miss. Tech. Rep. E-79-2. 